"This is an Accepted Manuscript of an article published by Taylor \& Francis Group in

International Journal of Listening on 21/05/2012

available online:

http://www.tandfonline.com/10.1080/10904018.2012.677702"

\title{
Eavesdropping as Listening Development
}

\author{
Kent Adelmann, Ph.D. \\ Senior Lecturer \\ Malmö University \\ SE-205 06 Malmö \\ Sweden \\ Kent.Adelmann@mah.se
}

\section{Overview/Abstract}

In ordinary life we are constantly imbued by listening and we seem to interact in different contextual dimensions of culture and society (Adelmann 2002, Linell 1998), both verbally and nonverbally. "Life by its very nature is dialogic. To live means to participate in dialogue", according to the Russian scholar Mikhail M. Bakhtin (1984:293).

So, in everyday life we get used to many kinds of situations where we hear conversations that we are actually not supposed to hear. For example, while we are waiting for the bus or subway we may listen to people next to us that appear to being having an argument.

Usually we do not notice all these routine situations. But sometimes we do notice some interaction and listen with some attention. We have more of an absentminded attention and rarely listen attentively. But what if we did? The activity in listening presented here takes advantage of our daily and personal listening experiences of eavesdropping and use it for the educational purpose of listening development.

\section{Learning Outcomes}

After completing this activity students will

- Engage in participant observation

- Direct their attention to the listening opportunities around them

- Listen with intention

- Increase listening ability

\section{Detailed Procedure}

1. Have students read sections of The Art of Listening (Adelmann 2009), such as different listening skills for different purposes (Wolvin \& Coakley, 1996 [1982]).

2. Give a lecture introducing listening reception, providing examples on observation as a social research method, and the ethical principles involved in such research.

3. Give students the listening homework, using the following instruction that originally comes from an idea by Margot Ely (1991): 
Time and place: Choose a time when you are not in a hurry, like a coffee break or lunch time. Then choose a place where you know there are a lot of people at this time of the day, like a restaurant or café, or at the central station, with people coming and going all the time.

Mission: Direct your attention and focus on an ongoing interaction next to you in the public setting. Just listen and observe. During your participant observation you may not interfere or influence interaction in any way. Do not take notes.

Questions: (1) What is the dialogue all about? (2) What is happening? (3) How do you feel when you listen to the interaction? Keep your focus on these questions so you can remember details when it comes time to write your notes.

Procedure: Pay attention for 5-10 minutes. Five minutes is enough for a novice. If the participants leave you may discreetly take notes without revealing yourself. Otherwise, you may leave the public setting when it is appropriate so that you are taking notes as soon as possible. Make a copy of your notes in your listening diary. Add your reflections of the experience as well.

4. On the next day of class, divide students into small groups of 5-7 members. Each student retells the eavesdropping episode to other group members and group members choose one episode to present to the entire class. Focus discussion on: What did you learn about the art of listening? What did you learn about yourself as a listener? What did you learn about participation observation?

\section{Theoretical Underpinnings and/or a Brief Rationale}

In western tradition eavesdropping is seen as rude and ill-mannered, even though blogs, reality programs and publishing of private conversations have changed the border between the public and the private sphere. But, when eavesdropping happens anyway, students can gain some knowledge and understanding of how we actually talk and listen to each other by eavesdropping on the conversations that continually go on around them. They can engage in a qualitative research method known as participant observation.

In qualitative research the researcher relies on observation and listening and assembles data through seeing and listening (Ely et al, 1991). Using Bryman's fourfold distinction in forms of ethnography, eavesdropping in the context of the activity presented here means that students have a covert (and not overt) role in a public (and not closed) setting (Bryman, 2008:404). According to Gold's classification of participant observer roles (cited in Bryman, 2008:411) the listener acts as a complete observer with a maximum of detachment from the members of the social setting.

From an ethical perspective covert observation does not "provide participants with the opportunity for informed consent (...) it entails deception", and it can also be taken as "a violation of the principle of privacy" (Bryman 2008:406). However, this activity causes no violation of ethical principles. Participants are not harmed, there is no invasion of privacy or deception. As a result informed consent is not an issue, because the individuals are not identified or identifiable and the observation is done in public spaces (Bryman 2008:118).

\section{Assessment of Learning}


During this exercise the students are using their listening diary, where they keep all their documented listening experiences. The listening diary comprises the documented events, reflections, responses from classmates, questions and self-assessments. Every now and then there will also be some comments and questions from the teacher. After a while you will eventually make some comparison and find some patterns. So, according to my experience, documented listening, like this exercise about eavesdropping, makes a good starting point for a potential listening development.

\section{Resources}

Adelmann, K. (2002) Att lyssna till röster. Ett vidgat lyssnandebegrepp i ett didaktiskt perspektiv [Listening to Voices: An extended notion of listening in an educational perspective].

Dissertation. Malmö: Dissertations from School of Teacher Education, Malmö University, Sweden. (January 2, 2012). Available with English summery at: http://dspace.mah.se/bitstream/handle/2043/6400/adelmann.pdf?sequence=1

Adelmann, K. (2009) Konsten att lyssna. Didaktiskt lyssnande i skola och utbildning [The Art of Listening: Pedagogical listening in school and education]. Lund: Studentlitteratur.

Bakhtin, M. (1984 [1929/1963]) Problems of Dostoevsky's Poetics (2 ${ }^{\text {nd }}$ ed.) Theory and History of Literature 8. C. Emerson (ed. and trans.). Manchester: Manchester University Press.

Bryman, A. (2008) Social Research Methods (3rd ed.). Oxford: Oxford University Press.

Ely, M. (with M. Anzul, T. Friedman, D. Garner and A. McCormack Steinmetz) (1991) Doing Qualitative Research: Circles within circles. London: Routledge Falner.

Linell, P. (1998) Approaching Dialogue: Talk, interaction and contexts in dialogical perspectives. Amsterdam/Philadelphia: John Benjamins Publishing Company.

Wolvin, A. D. and Coakley, C. G. (1996 [1982]) Listening (5 ${ }^{\text {th }}$ ed.). Boston, MA: McGraw-Hill. 